\begin{tabular}{lc}
\hline & ANNALES \\
& UNIVERSITATIS MARIAE CURIE-SKŁODOWSKA \\
LOL. V & SECTIO N \\
\hline
\end{tabular}

ISSN: 2451-0491 • e-ISSN: 2543-9340 - CC-BY 4.0 • DOI: 10.17951/en.2020.5.453-472

\title{
Escape from Etymology? A Corpus Study of Polish Adjectival Intensifiers
}

\section{Ucieczka od etymologii? Korpusowe studium polskich przysłówków wzmacniających}

\author{
Katarzyna Dziwirek \\ University of Washington. Department of Slavic Languages and Literatures \\ box 354335 , Seattle, WA 98125, USA \\ dziwirek@uw.edu \\ https://orcid.org/0000-0001-9401-2421
}

\begin{abstract}
Abstrakt. Używając Narodowego Korpusu Języka Polskiego (NKJP), autorka omawia 31 polskich przysłówków wzmacniających, aby określić stopień ich specyficzności semantycznej oraz dowolności łączenia się z przymiotnikami. Przysłówki wzmacniające wyrażają sądy, postawy i emocje osoby mówiącej. Autorka pokazuje, że większość przysłówków wzmacniających nie oddaliło się od swojej etymologii, mimo że są uważane za synonimy słowa bardzo: ich etymologiczne znaczenia wpływają na wybór przymiotnika. Najczęściej wzmacniane przymiotniki w NKJP to trudny, ważny i istotny.
\end{abstract}

Słowa kluczowe: intensyfikacja; przymiotnik; etymologia; łączliwość; specyficzność semantyczna

\begin{abstract}
Using the Polish National Corpus (NKJP), the author discusses 31 Polish reinforcing adverbs to determine the degree of their semantic specificity and freedom of connection with adjectives. Empowering adverbs express the person's judgement, attitudes, and emotions. The author shows that most of the reinforcing adverbs have not deviated from their etymology, even though they are considered synonyms of the word "very": their etymological meanings influence the choice of the adjective. The most frequently reinforced adjectives in NKJP are "difficult", "important" and "essential".
\end{abstract}

Keywords: intensification; adjective; etymology; connectivity; semantic specificity 


\section{INTRODUCTION}

According to Rodney Huddleston and Geoffrey Pullum (2002: 585), "intensifier" is a term for a modifier that makes no contribution to the propositional meaning of a clause but serves to enhance and give additional emotional context to the word it modifies. Dagmara Bałabaniak and Barbara Mitrenga (2015: 15) claim that lexical intensifiers are functional expressions with metapredicative functions. They go on to say that the meanings of magnitude, amount and intensity are intertwined in the semantics of intensifiers (ibidem: 53). In Degree Words, a seminal 1972 work, Dwight Bolinger (1972: 18) states: "Degree words afford a picture of fevered invention and competition that would be hard to come by elsewhere, for in their nature they are unsettled. They are the chief means of emphasis for speakers for whom all means of emphasis quickly grow stale and need to be replaced". Alan Partington (1993: 178) claims that intensifiers primarily serve a communicative function and "signal" that "what is being said is sincerely vouched for".

It is commonly believed that intensifiers tend to be short-lived and lose their specific meanings over time. Bolinger (1972: 18) quotes Agatha Christie: "At one period one said that things were »topping", and then that they were »too divine «, and then that they were »marvelous «, and that one »couldn't agree with you more«, and that you were »madly« fond of this, that, and the other". Urlike Stange (2017: 515) states that (her study supports) "the notion that intensifiers in general [...] are undergoing a process of delexicalization/grammaticalization. That is, they gain a purely grammatical function (intensification) at the expense of their semantic content".

The primary adjectival intensifier in Polish is bardzo ("very"). It occurs in the Polish National Corpus (NKJP) 330,099 times per 250 million words. The original meaning of bardzo has been lost (according to Bańkowski 2000: 33 its source "brzo meant "quickly or violently"), and since the second half of the $16^{\text {th }}$ century it has meant simply "intensively".

Elżbieta Janus (1981: 43-44) lists the following intensifiers which she considers to be relatively semantically bleached of meanings other than "very": diablo ("devilishly"), diabelnie ("devilishly"), cholernie ("damnedly"), kolosalnie ("colossally"), mocno ("strongly"), ogromnie ("hugely"), okropnie ("awfully"), piekielnie ("infernally"), potwornie ("terribly"), silnie ("strongly"), strasznie ("terribly"), straszliwie ("terribly"), szalenie ("madly"), wielce ("largely"), wysoce/wysoko ("highly"). She includes intensifiers like diabelnie ("devilishly") and piekielnie ("infernally"), because she says that they do not directly recall the notions of the "devil" or "hell" as they can be combined with opposite adjectives: diabelnie tadna dziewczyna ("devillishly pretty girl") and diabelnie brzydka dziewczyna 
("devilishly ugly girl"), piekielnie zdolna ("infernally clever") and piekielnie tępa ("infernally dull") (Janus 1981: 45)1.

Yet, we shall see that despite the fact that diabelnie can modify both members of an antonymic pair, it tends to be found most often with negative adjectives, showing that is has perhaps not escaped its etymology entirely. Likewise, we shall see that straszliwie and strasznie, both of which mean "terribly" and come from the same root, in fact combine with very different adjectives. Janus' comprehensive work was completed before the advent of linguistic corpora and was not influenced by frequencies of occurrence. Looking at the corpus data containing intensifiers today we can discern larger trends in their combinatorial properties. In fact, I will argue that most of the intensifiers Janus considered to be near synonyms of bardzo "very", are not semantically neutral and are still prisoners of their etymology. Their residual core meanings correlate with specific speaker attitudes and affect their adjectival collocations.

I consider 31 intensifiers in order to determine to what degree their vestigial meanings affect their collocations with adjectives. I also look at the phenomenon of intensification from the other side and investigate which types of adjectives can be modified by intensifiers and which tend to do so most frequently.

\section{INTENSIFIERS: ETYMOLOGY}

The 31 intensifiers I considered are listed below with their English dictionary translations as well as etymological meanings. Grammatically, they are all adverbs formed from adjectives. They are divided into six groups based on their meaning and combinatorial properties ${ }^{2}$.

\section{Highly specialized}

bezdennie "abysmally, hopelessly" (from bezdenny ["bottomless"], bez ["without"] and dno ["bottom"])

horrendalnie "horribly, awfully, exorbitantly, prohibitively" (from horrendalny ["horrible, horrid, exorbitant"])

1 Following a suggestion by Anna Wierzbicka, Janus proposes that the explications of meaning of diabelnie, piekielnie, etc. should include bardzo ("very") as well as an (inter)personal meaning component "this intrigues me" to account for the additional shades of meaning. In the definition of bardzo X ("very"), Wierzbicka (1969: 188) includes the element "it strikes me/I must pay attention to it", which is later reformulated as "I cannot not notice it", and later still as "I must say more than X" (Wierzbicka 1971: 132).

2 I do not consider adverbs such as absolutnie ("absolutely"), kompletnie ("completely"), zupetnie ("entirely") which refer to a full degree of a property or feature. 
skandalicznie "scandalously, shockingly, atrociously, outrageously, shamefully" (from skandaliczny ["scandalous"], skandal ["scandal, outrage"])

bajecznie "fabulously, incredibly, unbelievably, enormously, extremely" (from bajeczny ["fabulous, legendary, mythic"], bajka ["fairy tale"])

Angels, devils, heaven, hell

\begin{tabular}{|c|c|}
\hline anielsko & "angelically" (from anielski ["angelic, angel's"]) \\
\hline bosko & "divinely, heavenly" (from boski ["divine”]) \\
\hline diabelnie & $\begin{array}{l}\text { "devilishly, infernally, fiendishly, deucedly, cursedly, damnably" (from } \\
\text { diabet ["devil"] diabelny ["devilish"]) }\end{array}$ \\
\hline diabelsko & $\begin{array}{l}\text { "diabolically, fiendishly" (from diabet ["devil"] diabelski ["diabolical, } \\
\text { fiendish, hellish"]) }\end{array}$ \\
\hline diablo & $=$ diabelnie, archaic \\
\hline niebiańsko & "heavenly, divinely" (from niebo ["heaven, sky"]) \\
\hline nieludzko & $\begin{array}{l}\text { "inhumanly, barbarously, atrociously, terribly, awfully" (from nieludzki } \\
\text { ["inhuman"]) }\end{array}$ \\
\hline nieziemsko & "divinely" (from nieziemski ["unearthly"]) \\
\hline piekielnie & $\begin{array}{l}\text { "infernally, hellishly, like hell, awfully, confoundedly" (from piekto ["hell"], } \\
\text { piekielny ["infernal, hellish"]) }\end{array}$ \\
\hline szatańsko & "infernally" (from szatański ["infernal, Satan's”], szatan [“Satan”]) \\
\hline
\end{tabular}

\section{Madness-related}
obłędnie "madly, insanely, crazily" (from obłędny ["crazy"])
szalenie "very, extremely, awfully, terribly, like mad" (from szalony ["insane"])
szaleńczo "madly, insanely, dementedly, distractedly, recklessly, to distraction" (from szaleńczy ["reckless"])
wściekle "madly, furiously, awfully, frightfully, wildly, savagely” (from wściekty ["rabid, angry"])

\section{Negated}

$\begin{array}{ll}\text { bezmiernie } & \text { "immeasurably, infinitely, immensely" (from bez ["without"] and miara } \\ \text { niesamowicie } & \text { ["measure"]) } \\ & \text { "very, strangely, uncommonly, weirdly" (19 } 9^{\text {th }} \text {-century borrowing from } \\ & \text { Ukrainian, with unclear etymology: "unlike self" [Bańkowski 2000: 308] or } \\ & \text { "not-independent" [Boryś 2005: 362]) } \\ \text { niestychanie } & \text { "extremely, excessively, outrageously" (from niestychany ["unheard of"]) } \\ \text { niewiarygodnie } & \text { "incredibly, unbelievably" (from niewiarygodny ["unbelievable"]) } \\ \text { niezmiernie } & \text { "extremely, exceedingly, beyond measure, immensely, vastly" (from nie } \\ & \text { ["not"] and miara ["measure"]) }\end{array}$

\section{Terribly}

cholernie "damnedly, cursedly, awfully, terribly, like the deuce, like hell" (from cholera/cholerny ["bloody, awful”]) 


\begin{tabular}{|c|c|}
\hline okropnie & $\begin{array}{l}\text { "horribly, awfully, terribly, very, extremely, excessively, intensely" (from } \\
\text { okropny ["horrible"] original meaning related to kropić ["to splatter"]: } \\
\text { splattered } \rightarrow \text { dirty } \rightarrow \text { disgusting } \rightarrow \text { frightening [Boryś 2005: 389], or to okrop/ } \\
\text { ukrop ["hot liquid"] found in hell, thus, frightening [Bańkowski 2000: 405]) }\end{array}$ \\
\hline potwornie & $\begin{array}{l}\text { "hugely, stupendously, terribly" (from potworny ["monstrous, freaky, } \\
\text { horrible, hideous"] potwór ["monster"]) }\end{array}$ \\
\hline straszliwie & "terribly, horrifically" (from straszliwy ["horrific"], strach ["fear, terror"]) \\
\hline strasznie & $\begin{array}{l}\text { "terribly, frightfully, horribly, terrifically, awesomely, dreadfully" (from } \\
\text { straszny ["terrible, horrific, dreadful, frightful, gruesome"], strach ["fear, } \\
\text { terror"]) }\end{array}$ \\
\hline \multicolumn{2}{|l|}{ Ex-based } \\
\hline nadzwyczajnie & $\begin{array}{l}\text { "extraordinarily, excessively, extremely, not as usual" (from nad ["above/ } \\
\text { over"] and zwyczajny ["ordinary, common, usual, normal"]) }\end{array}$ \\
\hline niezwykle & $\begin{array}{l}\text { "extraordinarily, exceptionally, remarkably, uncommonly, unusually" (from } \\
\text { nie ["not"] and zwykty ["common, ordinary, usual, habitual"]) }\end{array}$ \\
\hline wyjątkowo & “exceptionally" (from wyjątkowy ["exceptional”], wyjatek [“exception”]) \\
\hline
\end{tabular}

Of the 31 intensifiers listed above, 23 could be said to derive from roots that are essentially negative in meaning (e.g. strasznie ["terribly"]), 5 clearly derive from positively valued terms (e.g. anielsko ["angelically"]), and 3 are attitudinally neutral (e.g. wyjatkowo ["exceptionally"]) ${ }^{3}$.

Christian Vosshagen (1999: 302) comments on English sentences like "It was terribly amusing"; "These examples show that originally negative expressions can be used adverbially to intensify positive ones without creating contradictions. The crucial meaning component here seems to be not the negative value of the concepts, but their intensity". These sentences are used in support of Vosshagen's claim that "forms of language use in which something is uttered to convey its opposite are metonymic" and that "a conceptual entity can be used to provide mental access to its opposite, which is closely associated with it within a conceptual structure" (ibidem: 289). He proposes that A CONCEPT STANDS FOR ITS OPPOSITE is a widespread metonymy underlying figurative speech (ibidem: 290).

As we shall see below, the corpus data I investigated suggests that the situation in Polish is more complicated than metonymy alone. There are also matters of register and intensifier's lexical preferences.

3 This is not an exhaustive list of Polish intensifiers. Others include bezgranicznie ("endlessly"), niebywale ("unusually"), niemożebnie ("impossibly"), nieskończenie ("infinitely"), rekordowo ("record-setting-ly"), wielce ("greatly"), wysoko/wysoce ("highly"), zadziwiajaco ("amazingly"), kolosalnie ("hugely"), mocno ("strongly"), ogromnie ("hugely"), etc. I am grateful to fellow Polish-T list members for these examples. 
Table 1 presents the numbers of concordances and adjectival collocations in the NKJP from most to least frequent. The numbers in the second column are concordances, or the total number of occurrences in the corpus (not only when modifying adjectives). Even the top words in the table do not come close to the number of occurrences of bardzo "very" $(330,099)$. The numbers in the third column represent the number of adjectives which were found with the intensifier 5 times or more. This does not mean that the intensifier does not occur with other adjectives, it merely indicates how many adjectives it collocates with frequently.

Table 1. Concordances and collocations of Polish intensifiers in NKJP

\begin{tabular}{|c|c|c|c|}
\hline Intensifier & Translation & Concordances & Collocations $(5$ or $>$ ) \\
\hline niezwykle & unusually & 18,954 & 273 \\
\hline wyjatkowo & exceptionally & 11,090 & 265 \\
\hline strasznie & terribly & 9,002 & 112 \\
\hline niezmiernie & immeasurably & 3,436 & 92 \\
\hline okropnie & terribly & 2,400 & 21 \\
\hline niestychanie & unheard-of-ly & 2,379 & 114 \\
\hline szalenie & madly & 2,022 & 88 \\
\hline niesamowicie & uncommonly & 1,096 & 42 \\
\hline cholernie & damnedly & 1,066 & 36 \\
\hline potwornie & monstrously & 1,045 & 76 \\
\hline straszliwie & terribly & 1,021 & 21 \\
\hline wściekle & madly & 677 & 4 \\
\hline piekielnie & infernally & 605 & 22 \\
\hline niewiarygodnie & unbelievably & 477 & 18 \\
\hline bosko & divinely & 389 & 1 \\
\hline nadzwyczajnie & unusually & 377 & 10 \\
\hline bajecznie & fabulously & 341 & 5 \\
\hline nieludzko & inhumanly & 219 & 10 \\
\hline skandalicznie & scandalously & 204 & 4 \\
\hline szaleńczo & madly & 174 & 3 \\
\hline diabelnie & devilishly & 135 & 2 \\
\hline horrendalnie & exorbitantly & 90 & 2 \\
\hline obtędnie & madly & 87 & 3 \\
\hline nieziemsko & divinely & 69 & 2 \\
\hline anielsko & angelically & 45 & 2 \\
\hline bezmiernie & immeasurably & 44 & 0 \\
\hline szatańsko & infernally & 30 & 0 \\
\hline bezdennie & abysmally & 29 & - \\
\hline diabelnie & diabolically & 28 & 0 \\
\hline niebiańsko & heavenly & 23 & 1 \\
\hline
\end{tabular}

Source: Author's own study. 
Looking at Table 1 we observe that in general larger numbers in the second column correspond to larger numbers in the third one, that is, the more common the intensifier is, the more adjectives it tends to collocate with. This pattern is not absolute though, as wyjatkowo ("exceptionally") and strasznie ("terribly") occur in the corpus with similar frequency, but the number of frequent collocations for wyjatkowo is more than double that of strasznie. This might indicate that strasznie ("terribly") perhaps retains some of its root meaning of strach ("fear", "terror"), which affects its range of combinations. But as we shall see, in the case of strasznie, it is more likely a matter of register. Unlike terribly in English, the Polish strasznie retains a slightly slangy, gushing flavor and cannot combine with adjectives of higher register. Wyjatkowo ("exceptionally") on the other hand has no slangy teenage overtones and can combine with a wide variety of adjectives ${ }^{4}$.

In general, a larger number of collocations is indicative of a higher degree of semantic "bleaching" of the intensifier. That is, that the intensifier has mostly lost its core meaning and shifted to simply indicate intensity. Conversely, the smaller number of collocations means that the sense of the root adjective is still present in the adverb/intensifier's meaning and constrains the words it can combine with. We shall consider intensifiers and their meanings first, adjectives and their preferences second.

\section{THE MEANINGS AND PREFERENCES OF INTENSIFIERS}

\section{Highly specialized intensifiers: contempt, condemnation, awe}

Let us start with the intensifiers with the fewest frequent collocations.

Bezdennie ("abysmally"), literally "bottomlessly", tends to occur primarily with one adjective: gtupi ("stupid"). The comparable English adverb "abysmally" collocates with "stupid", but also "low", "small", "insufficient" in the British National Corpus (BNC). Horrendalnie collocates with two adjectives, drogi ("expensive") and wysoki ("high"). Even though its root adjective horrendalny was originally borrowed into Polish (from Latin via German horrend [Bańkowski 2000: 531]) with the meaning of "horrible", "terrible", it eventually specialized to primarily mean "prohibitive, exorbitant" and is found most often with words like

4 Similarly, though the frequency of niesłychanie ("unheard-of-ly") is a sixth of that of strasznie, they have a comparable number of collocations. Also, some intensifiers tend to occur primarily with verbs and have very few adjectival collocations (c.f. bosko ["divinely"] which is most often found with wyglądać ["to look/appear"], brzmieć ["to sound"], pachnieć ["to smell"], smakować ["to taste"], etc.). 
koszt ("cost"), czynsz ("rent"), podatek ("tax"), wydatek ("expense"), cena ("price"), etc. The adverb horrendalnie follows suit. $74 \%$ of occurrences of horrendalnie were with these two adjectives.

Table 2. Top 5 collocations (of 5 or > adjectives) for each intesifier

\begin{tabular}{|c|c|c|c|c|c|}
\hline $\begin{array}{c}\text { bajecznie } \\
\text { "fabulously" }\end{array}$ & $\begin{array}{c}\text { kolorowy } \\
\text { "colorful" }\end{array}$ & $\begin{array}{c}\text { bogaty } \\
\text { "rich" }\end{array}$ & $\begin{array}{c}\text { prosty } \\
\text { "simple" }\end{array}$ & $\begin{array}{c}\text { piękny } \\
\text { "beautiful" }\end{array}$ & $\begin{array}{c}\text { tani } \\
\text { "cheap" }\end{array}$ \\
\hline $\begin{array}{c}\text { skandalicznie } \\
\text { "scandalously" }\end{array}$ & $\begin{array}{c}\text { niski } \\
\text { "short/low" }\end{array}$ & $\begin{array}{c}\text { maty } \\
\text { "small" }\end{array}$ & $\begin{array}{c}\text { wysoki } \\
\text { "high" }\end{array}$ & $\begin{array}{c}\text { zty } \\
\text { "bad" }\end{array}$ & \\
\hline $\begin{array}{c}\text { horrendalnie } \\
\text { "exorbitantly" }\end{array}$ & $\begin{array}{c}\text { wysoki } \\
\text { "high" }\end{array}$ & $\begin{array}{c}\text { drogi } \\
\text { "expensive" }\end{array}$ & & & \\
\hline $\begin{array}{c}\text { bezdennie } \\
\text { "abysmally" }\end{array}$ & $\begin{array}{c}\text { gtupi } \\
\text { "stupid" }\end{array}$ & & & & \\
\hline
\end{tabular}

Source: Author's own study.

Another borrowed and fairly specialized intensifier is skandalicznie ("scandalously"). It collocates with four adjectives: niski ("short"), zły ("bad"), maty ("small"), and wysoki ("high"). Both skandalicznie and its English equivalent "scandalously" imply condemnation and indignation. "Scandalously" occurs with "late", "long", "low", "short", "neglected", "wasteful", etc. in the BNC.

In contrast, bajecznie ("fabulously"), which derives from the adjective $b a$ jeczny ("legendary", "mythical", "fabulous", "untold") and less directly from $b a j$ $k a$ ("fairy tale", "fable"), correlates with primarily positive adjectives: kolorowy ("colorful"), bogaty ("rich/wealthy"), prosty ("simple"), tani ("cheap") and piękny ("beautiful"). The English "fabulously" collocates most often with "rich" and "wealthy", but also "strong", "dressed", "expensive", etc.

The four intensifiers considered here are highly semantically marked and occur with select few adjectives. They imply intensity but also clear speaker judgments based on their core meanings: contempt in the case of bezdennie ("abysmally"), indignation and condemnation for horrendalnie ("exorbitantly") and skandalicznie ("scandalously"), and wonder/amazement mixed with a tinge of envy for bajecznie ("fabulously").

\section{Gods, angels, humans, and devils}

Turning to earth, heaven, and hell, the intensifier nieludzko ("inhumanly") tends to modify a few positive adjectives (doskonaty ["perfect"], piękny ["beautiful"], wielki ["great"], cierpliwy ["patient"]), but is mostly found with negative and neutral ones (zmęczony ["tired"], traktowany ["treated"], cierpiacy ["suffering"], zimny ["cold"], okrutny ["cruel"], and ciężki ["heavy/difficult"]). Being inhuman 
is viewed as mostly pejorative and nieludzko contributes the meaning of negative evaluation when combined with an arguably neutral adjective or participle such as zimny ("cold") and traktowany ("treated").

Table 3. Top 5 collocations (of 5 or $>$ adjectives) for each intensifier

\begin{tabular}{|c|c|c|c|c|c|}
\hline $\begin{array}{l}\text { nieludzko } \\
\text { "inhumanly" }\end{array}$ & $\begin{array}{c}\text { zmęczony } \\
\text { "tired" }\end{array}$ & $\begin{array}{l}\text { traktowany } \\
\text { "treated" }\end{array}$ & $\begin{array}{l}\text { cierpiacy } \\
\text { "suffering" }\end{array}$ & $\begin{array}{l}\text { zimny } \\
\text { "cold" }\end{array}$ & $\begin{array}{l}\text { doskonaty } \\
\text { "perfect" }\end{array}$ \\
\hline $\begin{array}{l}\text { nieziemsko } \\
\text { "divinely" }\end{array}$ & $\begin{array}{c}\text { piękny } \\
\text { "beautiful" }\end{array}$ & $\begin{array}{l}\text { przystojny } \\
\text { "handsome" }\end{array}$ & & & \\
\hline $\begin{array}{l}\text { niebiańsko } \\
\text { "heavenly" }\end{array}$ & $\begin{array}{c}\text { piękny } \\
\text { "beautiful" }\end{array}$ & & & & \\
\hline $\begin{array}{c}\text { anielsko } \\
\text { "angelically" }\end{array}$ & $\begin{array}{l}\text { cierpliwy } \\
\text { "patient" }\end{array}$ & $\begin{array}{c}\text { piękny } \\
\text { "beautiful" }\end{array}$ & & & \\
\hline $\begin{array}{c}\text { bosko } \\
\text { "divinely" }\end{array}$ & $\begin{array}{l}\text { święty } \\
\text { "holy" }\end{array}$ & & & & \\
\hline $\begin{array}{c}\text { diabelnie } \\
\text { "devilishly" }\end{array}$ & $\begin{array}{l}\text { trudny } \\
\text { "difficult" }\end{array}$ & $\begin{array}{c}c i e ̨ z \dot{z} k i \\
\text { "difficult" }\end{array}$ & & & \\
\hline $\begin{array}{l}\text { piekielnie } \\
\text { "infernally" }\end{array}$ & $\begin{array}{l}\text { trudny } \\
\text { "difficult" }\end{array}$ & $\begin{array}{c}\text { drogi } \\
\text { "expensive" }\end{array}$ & $\begin{array}{l}\text { mocny } \\
\text { "strong" }\end{array}$ & $\begin{array}{l}\text { inteligentny } \\
\text { "intelligent" }\end{array}$ & $\begin{array}{c}\text { silny } \\
\text { "strong" }\end{array}$ \\
\hline
\end{tabular}

Source: Author's own study.

In contrast, nieziemsko, translated as "divinely", but literally "not-of-the-earth" and niebiańsko ("heavenly") correlate primarily with positive adjectives describing appearance; niebiańsko with piękny ("beautiful") and nieziemsko with piękny and przystojny ("handsome"). Anielsko ("angelically") also combines with piękny as well as with cierpliwy ("patient") ${ }^{5}$. Bosko ("divinely") does not occur with many adjectives, its only collocation with more than 5 tokens was święty ("holy").

Devil- and hell-based intensifiers, unsurprisingly, combine with different adjectives still. Diabelnie ("devilishly") is found with trudny ("difficult") and ciężki ("heavy/difficult").Diablo (slightly archaic) with skomplikowany ("complicated"), inteligentny ("intelligent") and trudny ("difficult"). Diabelsko ("diabolically") returned no collocations of 5 or more, but the manual search yielded examples with drogi ("expensive"), wykrzywiony ("twisted"), szokujacy ("shocking"), dobry

5 Janus (1981: 37-40) argues that definitions of intensifiers such as anielsko must include a reference to the meaning of "angel" since their meaning is not reducible to "very". This is supported by the fact that they can be used in opposition to bardzo as in: Ten człowiek jest nie tylko bardzo cierpliwy ale wręcz anielsko cierpliwy ("This man is not just very patient, he is simply angelically patient") and by the limited number of collocations found with these intensifiers. Also, as mentioned above piekielnie ("infernally") and diabelsko ("devilishly") can combine with both positive and negative adjectives, while anielsko ("angelically") cannot modify an adjective with a negative meaning. 
("good"). None with the Polish version of "clever", which is the adjective most frequently associated with the English diabolically. Szatańsko ("infernally") which derives from szatański ("Satan's") and szatan ("Satan") also returned no collocations greater than 5, but was found to occur with przystojny ("handsome"), doskonaty ("perfect"), and $z$ dolny ("talented"). The final word in this group, piekielnie ("infernally", "hellishly"), combines with the most diverse group of adjectives (22 collocations), suggesting that it is most semantically bleached.

In summary, it seems that the intensifiers in this group are highly specialized and retain the core meaning of their root words. Those which refer to positively valued concepts: god, heaven, angels, occur only with positive adjectives often referring to appearance/beauty. Those which reference devil, Satan, and hell are more complex. The devil seems to be associated with difficulty and complications, Satan - with envied qualities (beauty, perfection) and seems to imply grudging admiration. A similar sense is involved when nieludzko is used with positive adjectives: szatańsko przystojny or nieludzko przystojny ("inhumanly/ infernally handsome") suggest that the speaker is so struck by the looks of someone that they suspect that they could not have come about naturally.

A final note on this group regards the differences in conceptualizations of angels and devils in Polish and English. In English, "diabolically" often correlates with "clever" and "angelically" - with "good". Neither of these adjectives were found as greater than 5 collocations of Polish diabelsko and anielsko. This suggests that angels and devils are conceived of slightly differently in the two cultures. In Polish, the primary attribute of angels is patience and the main function of devils is trouble-making and making things difficult for us.

\section{Madly}

Of the four intensifiers in this group, two relate to the noun szat which means "madness" but also "fury", "rage", "a state of ferment", "unrest", "restlessness", "tumult", etc." The two adjectives which form the basis of these intensifiers szalony ("mad", "crazy", "insane") and szaleńczy ("mad", "reckless") show the different extensions of the meaning of the base noun ${ }^{6}$. A state of ferment can be interpreted as insanity (szalony), anger (the verb szaleć "to rage"), or as great strength, bravery, zeal, and recklessness (szalony and szaleńczy).

\footnotetext{
6 Actually, szaleńczy is derived from szat via szaleniec ("a crazy, reckless person").
} 
Pobrane z czasopisma Annales N - Educatio Nova http://educatio.annales.umcs.pl Data: 26/04/2023 12:05:37

Escape from Etymology? A Corpus Study of Polish Adjectival Intensifiers 463

Table 4. Top 5 collocations (of 5 or > adjectives) for each intensifier

\begin{tabular}{|c|c|c|c|c|c|}
\hline $\begin{array}{c}\text { szalenie } \\
\text { "madly" }\end{array}$ & $\begin{array}{c}\text { ważny } \\
\text { "important" }\end{array}$ & $\begin{array}{c}\text { trudny } \\
\text { "difficult" }\end{array}$ & $\begin{array}{c}\text { istotny } \\
\text { "essential" }\end{array}$ & $\begin{array}{c}\text { ciekawy } \\
\text { "interesting" }\end{array}$ & $\begin{array}{c}\text { groźny } \\
\text { "threatening" }\end{array}$ \\
\hline $\begin{array}{c}\text { szaleńczo } \\
\text { "madly" }\end{array}$ & $\begin{array}{c}\text { zakochany } \\
\text { "in love" }\end{array}$ & $\begin{array}{c}\text { odważny } \\
\text { "brave" }\end{array}$ & $\begin{array}{c}\text { ambitny } \\
\text { "ambitious" }\end{array}$ & & \\
\hline $\begin{array}{c}\text { obłędnie } \\
\text { "madly" }\end{array}$ & $\begin{array}{c}d z i k i \\
\text { "wild" }\end{array}$ & $\begin{array}{c}\text { skomplikowany } \\
\text { "complicated" }\end{array}$ & $\begin{array}{c}\text { wysoki } \\
\text { "tall" }\end{array}$ & & \\
\hline $\begin{array}{c}\text { wściekle } \\
\text { "madly" }\end{array}$ & $\begin{array}{c}\text { różowy } \\
\text { "pink" }\end{array}$ & $\begin{array}{c}\text { głodny } \\
\text { "hungry" }\end{array}$ & $\begin{array}{c}\text { kolorowy } \\
\text { "colorful" }\end{array}$ & $\begin{array}{c}\text { czerwony } \\
\text { "red" }\end{array}$ & \\
\hline
\end{tabular}

Source: Author's own study.

The two have very different distributions. Szaleńczo is fairly rare and occurs with three main adjectives: zakochany ("in love"), odwazny ("brave") and ambitny ("ambitious"). It seems that to be in love, to be brave and to have ambitions or ideas above your station all require a modicum of madness or recklessness. By comparison, English "recklessly" does not function frequently as an intensifier of adjectives. It is most often found with verbs such as "buy", "wander", "drive", "interfere", "say", etc. Szalenie, on the other hand, is the sixth most common intensifier considered here, with 88 adjectival collocations of five or more. It is not pragmatically marked and can be used in all registers.

Obtędnie is related to the noun obtęd ("madness", "insanity", "lunacy", "dementia", "folly") and the adjective obtędny - "mad", "insane", "demented". It has only three collocations of five or more adjectives. Finally, the adverb wściekle "madly, wildly, savagely" from wściekty ("rabid", "angry", "mad") has four adjectival collocations. One, gtodny ("hungry"), would probably be the adjective most people would think of as co-occurring with wściekle, as it is almost a set phrase. This is similar to "ravenously" and its connection with "hungry" in English. The other three are color adjectives (różowy ["pink"], kolorowy ["colorful"] and czerwony ["red"]). When used with a name of a color wściekle means "very intense": wściekle różowy corresponds to English "shocking pink".

Of the four intensifiers derived from words which mean "mad", three are fairly specialized and occur with select adjectives, while the fourth, szalenie is among the most common adverbs used to modify adjectives in Polish and there seems to be little connection any more to the meaning of szat ("rage", "fury", "madness") which is at its root.

7 There is also an adjective obtakańczy derived from obłakaniec ("mad person"). The adverb obtakańczo is v. rare in the corpus (102 instances) and is found only with single adjectives drogi ("expensive"), antysemicki ("anti-Semitic"), zazdrosny (“jealous"), żótty ("yellow”), zaciekawiony ("intrigued"). 


\section{Crossing a line: negated intensifiers, positive adjectives}

The general meaning of this group of adverbs seems to be crossing a limit: a quality expressed by the modified adjective can be beyond belief (niewiarygodnie ["unbelievably"]), beyond measure (niezmiernie, bezmiernie ["immeasurably"]), human knowledge (niestychanie ["unheard-of-ly"]), or unlike our human selves (niesamowicie ["uncommonly"]). ${ }^{8}$ Niezmiernie ("immeasurably") is the fourth most common intensifier considered here, niestychanie ("unheard-of-ly") is next, and niesamowicie ("uncommonly") is ninth.

Table 5. Top 5 collocations (of 5 or $>$ adjectives) for each intensifier

\begin{tabular}{|c|c|c|c|c|c|}
\hline $\begin{array}{c}\text { niezmiernie } \\
\text { "immesurably" }\end{array}$ & $\begin{array}{c}\text { ważny } \\
\text { "important" }\end{array}$ & $\begin{array}{c}\text { trudny } \\
\text { "difficult" }\end{array}$ & $\begin{array}{c}\text { istotny } \\
\text { "essential" }\end{array}$ & $\begin{array}{c}\text { wdzięczny } \\
\text { "grateful" }\end{array}$ & $\begin{array}{c}\text { ciekawy } \\
\text { "interesting" }\end{array}$ \\
\hline $\begin{array}{c}\text { niestychanie } \\
\text { "unheard-of" }\end{array}$ & $\begin{array}{c}\text { ważny } \\
\text { "important" }\end{array}$ & $\begin{array}{c}\text { trudny } \\
\text { "difficult" }\end{array}$ & $\begin{array}{c}\text { istotny } \\
\text { "essential" }\end{array}$ & $\begin{array}{c}\text { skomplikowany } \\
\text { "complicated" }\end{array}$ & $\begin{array}{c}\text { silny } \\
\text { "strong" }\end{array}$ \\
\hline $\begin{array}{c}\text { niesamowicie } \\
\text { "uncommonly" }\end{array}$ & $\begin{array}{c}\text { duży } \\
\text { "big" }\end{array}$ & $\begin{array}{c}\text { ważny } \\
\text { "important" }\end{array}$ & $\begin{array}{c}\text { trudny } \\
\text { "difficult" }\end{array}$ & $\begin{array}{c}\text { silny } \\
\text { "strong" }\end{array}$ & $\begin{array}{c}\text { szybki } \\
\text { "fast" }\end{array}$ \\
\hline $\begin{array}{c}\text { niewiarygodnie } \\
\text { "unbelievably" }\end{array}$ & $\begin{array}{c}\text { wysoki } \\
\text { "high/tall" }\end{array}$ & $\begin{array}{c}\text { trudny } \\
\text { "difficult" }\end{array}$ & $\begin{array}{c}\text { wielki } \\
\text { "great/large" }\end{array}$ & $\begin{array}{c}\text { szybki } \\
\text { "fast" }\end{array}$ & $\begin{array}{c}\text { niski } \\
\text { "short" }\end{array}$ \\
\hline
\end{tabular}

Source: Author's own study.

Interestingly, these adverbs tend to modify mostly positive adjectives. Barring trudny ("difficult"), seemingly the most modified adjective in Polish, niesamowicie ("uncommonly") occurs almost uniquely with positive adjectives and participles, its only negative collocation is skomplikowany ("complicated"). Out of $114 \mathrm{col}$ locations for niestychanie and 92 collocations of niezmiernie only 15 of each adverb's collocations can be characterized as negative (including for both intensifiers bolesny ["painful"], krytyczny ["critical"], przykry ["sad/painful"], smutny ["sad"], szkodliwy ["harmful"], etc.). Niewiarygodnie and bezmiernie also have very few collocations with negative adjectives. Thus, adverbs which contain a negative prefix nie- "not/un-" or bez- "without" tend to modify mostly positive features.

\section{Terribly: negative adjectives}

This group includes some of the most commonly used intensifiers, which are often translated into English as "terribly". Two of them strasznie and straszliwie derive from adjectives based on the root strach ("fear", "terror"). They are

8 Bezdennie ("abysmally") and nieziemsko ("divinely") also belong to this broad category, but have been discussed above, niezwykle ("exceptionally") is discussed below. 
often listed as synonyms in dictionaries, yet their distribution is quite different. Strasznie is very common and occurs with all kinds of adjectives, though as mentioned above its use is constrained by its slightly slangy, gushing register. The frequency of straszliwie is much lower and it is found only with negative adjectives/participles. It occurs mostly with participles, e.g. okaleczony ("maimed"), wyniszczony ("ravaged"), zmasakrowany ("massacred"), wychudzony ("emaciated"), poparzony ("burned"), etc. With these and other participles the meaning of straszliwie is much closer to "horrifically" than to the milder "terribly". But when combined with the few adjectives that it is attested with (gtodny ["hungry"], samotny ["lonely"], bolesny ["painful"], brudny ["dirty"], smutny ["sad"], ciężki ["difficult"], trudny ["difficult"]), the meaning is closer to "terribly" and does not seem to evoke the same extreme degree of horror and dismay as when it is used with participles.

Table 6. Top 5 collocations (of 5 or > adjectives) for each intensifier

\begin{tabular}{|c|c|c|c|c|c|}
\hline $\begin{array}{c}\text { strasznie } \\
\text { "terribly" }\end{array}$ & $\begin{array}{c}\text { trudny } \\
\text { "difficult" }\end{array}$ & $\begin{array}{c}\text { zmęczony } \\
\text { "tired" }\end{array}$ & $\begin{array}{c}\text { nudny } \\
\text { "boring" }\end{array}$ & $\begin{array}{c}\text { maty } \\
\text { "small" }\end{array}$ & $\begin{array}{c}\text { smutny } \\
\text { "sad" }\end{array}$ \\
\hline $\begin{array}{c}\text { straszliwie } \\
\text { "terribly" }\end{array}$ & $\begin{array}{c}\text { okaleczony } \\
\text { "maimed" }\end{array}$ & $\begin{array}{c}z m e ̨ c z o n y \\
\text { "tired" }\end{array}$ & $\begin{array}{c}\text { zniszczony } \\
\text { "ruined" }\end{array}$ & $\begin{array}{c}\text { trudny } \\
\text { "difficult" }\end{array}$ & $\begin{array}{c}\text { zaniedbany } \\
\text { "neglected" }\end{array}$ \\
\hline $\begin{array}{c}\text { okropnie } \\
\text { "terribly" }\end{array}$ & $\begin{array}{c}\text { nudny } \\
\text { "boring" }\end{array}$ & $\begin{array}{c}z m e ̨ c z o n y \\
\text { "tired" }\end{array}$ & $\begin{array}{c}\text { smutny } \\
\text { "sad" }\end{array}$ & $\begin{array}{c}\text { głodny } \\
\text { "hungry" }\end{array}$ & $\begin{array}{c}\text { drogi } \\
\text { "expensive" }\end{array}$ \\
\hline $\begin{array}{c}\text { potwornie } \\
\text { "terribly" }\end{array}$ & $\begin{array}{c}z \text { męczony } \\
\text { "tired" }\end{array}$ & $\begin{array}{c}\text { drogi } \\
\text { "expensive" }\end{array}$ & $\begin{array}{c}\text { nudny } \\
\text { "boring" }\end{array}$ & $\begin{array}{c}\text { trudny } \\
\text { "difficult" }\end{array}$ & $\begin{array}{c}\text { ciężki } \\
\text { "difficult" }\end{array}$ \\
\hline $\begin{array}{c}\text { cholernie } \\
\text { "damnedly" }\end{array}$ & $\begin{array}{c}\text { trudny } \\
\text { "difficult" }\end{array}$ & $\begin{array}{c}z a z d r o s n y \\
\text { "jealous" }\end{array}$ & $\begin{array}{c}\text { drogi } \\
\text { "expensive" }\end{array}$ & $\begin{array}{c}\text { szczęśliwy } \\
\text { "happy" }\end{array}$ & $\begin{array}{c}\text { dobry } \\
\text { "good" }\end{array}$ \\
\hline
\end{tabular}

Source: Author's own study.

At the root of okropnie is either splatter/dirt or hot liquid found in hell and while the etymology is not at all transparent to Polish speakers, this intensifier is most often found with negative adjectives. Out of 21 collocations the only two with positive meaning referred to size: $d u \dot{z} y$ ("big") and wielki ("great"). Potwornie, on the other hand, has a very transparent root: potwór ("monster"), so its literal translation is "monstrously". It, too, rarely occurs with positive adjectives (7 out of 76 collocations). Cholernie, whose link to cholera ("cholera") a terrible disease, is quite clear, ${ }^{9}$ would seem to fall in the same category. But cholera is not only a name of a disease, it is also a mild swearword in Polish (since the $19^{\text {th }}$ century [Bańkowski 2000: 142]), used to express not only anger

9 Though its earliest uses in Polish (16 $6^{\text {th }}$ century, Bańkowski 2000: 142) refer to one of the four humors which formed the basis of medieval medicine. 
or frustration, but equally often astonishment and admiration and cholernie is not restricted to modifying negative adjectives.

With the exception of the very common strasznie ("terribly") and the slangy cholernie, the intensifiers in this group, which are most often translated into English as "terribly", "awfully" tend to modify negative adjectives and participles.

\section{Exceptionally}

The intensifiers in this group are very prolific and collocate with diverse adjectives. The same seems to be true in English: "exceptionally" occurs in the BNC 898 times with a wide range of adjectives ("strong", "good", "hard", "free", "long", "difficult", "generous", "poor", etc.)

Table 7. Top 5 collocations (of 5 or > adjectives) for each intensifier

\begin{tabular}{|c|c|c|c|c|c|}
\hline $\begin{array}{c}\text { niezwykle } \\
\text { "unusually" }\end{array}$ & $\begin{array}{c}\text { ważny } \\
\text { "important" }\end{array}$ & $\begin{array}{c}\text { trudny } \\
\text { "difficult" }\end{array}$ & $\begin{array}{c}\text { istotny } \\
\text { "essential" }\end{array}$ & $\begin{array}{c}\text { ciekawy } \\
\text { "interesting" }\end{array}$ & $\begin{array}{c}\text { cenny } \\
\text { "precious" }\end{array}$ \\
\hline $\begin{array}{c}\text { wyjatkowo } \\
\text { "exceptionally" }\end{array}$ & $\begin{array}{c}\text { trudny } \\
\text { "difficult" }\end{array}$ & $\begin{array}{c}\text { duży } \\
\text { "big" }\end{array}$ & $\begin{array}{c}\text { dobry } \\
\text { "good" }\end{array}$ & $\begin{array}{c}\text { wysoki } \\
\text { "tall" }\end{array}$ & $\begin{array}{c}\text { piękny } \\
\text { "beautiful" }\end{array}$ \\
\hline $\begin{array}{c}\text { nadzwyczajnie } \\
\text { "extraordinarily" }\end{array}$ & $\begin{array}{c}\text { wysoki } \\
\text { "tall" }\end{array}$ & $\begin{array}{c}\text { wielki } \\
\text { "great/large" }\end{array}$ & $\begin{array}{c}\text { duży } \\
\text { "big" }\end{array}$ & $\begin{array}{c}\text { trudny } \\
\text { "difficult" }\end{array}$ & $\begin{array}{c}\text { piękny } \\
\text { "beautiful" }\end{array}$ \\
\hline
\end{tabular}

Source: Author's own study.

\section{Summary}

We have seen that the core meanings of intensifiers do affect the range of adjectives they can modify and convey not only the speakers' assessment of the intensity of a feature, but also their perceptions and evaluations. Other than the register-neutral "exceptional" group, most intensifiers we considered show distinct preferences for specific types of adjectives and imply attitudes ranging from awe, approbation and (sometimes grudging) admiration to indignation, condemnation and contempt. We next turn to adjectives and examine which types of Polish adjectives tend to be modified by intensifiers.

\section{ADJECTIVES AND THEIR PREFERENCES}

Intensification of adjectives implies two things: i) inherent gradablity of the feature modified by the intensifier (e.g. bardzo prostopadty ["very perpendicular"] is impossible), and ii) the speaker's perception and evaluation of reality. Adding an intensifier to an adjective suggests that a feature denoted by it is markedly different when compared to another object with the same feature. 
Many of the intensifiers are hyperbolic. All of them provide information about the speaker's perception of reality.

Which adjectives can be modified by an intensifier? Janus (1981: 80) proposed that the primary type of a modifiable adjective is a parametric expression. She defines parametric adjectives as those which denote measurable amounts ( $d u \dot{z} y$ ["big"], dtugi ["long"]) and whose basic form is semantically more complex than the comparative (e.g. duży ["big"] is defined as "bigger than normal/expected"). Parametric adjectives typically enter into antonymic relations and both elements of the antonymic pair can be intensified (maty ["small"] as well as duży ["big"]). In addition to parametric adjectives, which include expression of size, volume, temperature, density, weight, loudness, strength, age/length of time.

Janus (1981: 131-134) lists the following types of adjectives as modifiable by intensifiers: i) adjectives directly relating to amounts (e.g. liczny ["numerous"]), ii) adjectives referring to evaluations or feelings: positive and negative evaluation, positive and negative feelings, neutral evaluations and feelings, iii) adjectives relating to physical/physiological feelings and states including smell and taste, and iv) adjectives relating to change of state (e.g. blady ["pale"], opalony ["tanned"], siwy ["grey-haired"]).

Renata Grzegorczykowa's (1975) answer to the question of which adjectives can be modified by intensifiers is less detailed than Janus'. She suggests three groups (Grzegorczykowa 1975: 40): i) those which refer to measurable features and amounts ("tall"/"short"), ii) those expressing judgments ("good"/"bad"), and iii) psychological features (emotions, e.g. "sad"/"happy", but also "boring"/"interesting", "smart"/"stupid, "brave"/"afraid", etc.).

We shall verify Janus' and Grzegorczykowa's claims in two ways: by looking at the most robust collocations for each intensifier (Table 8), and by trying to determine which adjectives tend to pair up with intensifiers by considering those that are found with at least five of ten intensifiers (Table 9).

Table 8 lists the intensifiers in the same order as in Table 1, from the most to least frequent in terms of total occurrences. It also lists their top five adjectival collocations in order of decreasing frequency from left to right, i.e. second column gives the most numerous collocation.

The top nine most frequent adverbs in Table 8 tend to occur with similar adjectives, while the following intensifiers (beginning with straszliwie ["horrifically"]) retain more of their core meaning and collocate with more specific adjectives. Based on the data in Table 8, the most frequent collocation for the top six intensifiers turns out to be the adjective trudny ("difficult"), it is the number one or two collocation for all six. It also appears among the top five collocations for eight other intensifiers, and, as we shall see in Table 9, it is the most often modified adjective 
in our data. Trudny belongs to Grzegorczykowa's group of adjectives expressing judgments and Janus' parametric adjectives, and it is perhaps unsurprising that human beings (or perhaps Poles) like to exaggerate the difficulty of the tasks or problems they encounter by modifying it with intensifiers.

Table 8. Top 5 collocations (of 5 or $>$ adjectives) for each intensifier

\begin{tabular}{|c|c|c|c|c|c|}
\hline $\begin{array}{l}\text { niezwykle } \\
\text { "unusually" }\end{array}$ & $\begin{array}{c}\text { ważny } \\
\text { "important" }\end{array}$ & $\begin{array}{l}\text { trudny } \\
\text { "difficult" }\end{array}$ & $\begin{array}{c}\text { istotny } \\
\text { "essential" }\end{array}$ & $\begin{array}{c}\text { ciekawy } \\
\text { "interesting" }\end{array}$ & $\begin{array}{c}\text { cenny } \\
\text { "precious" }\end{array}$ \\
\hline $\begin{array}{c}\text { wyjatkowo } \\
\text { "exeptionally" }\end{array}$ & $\begin{array}{c}\text { trudny } \\
\text { "difficult" }\end{array}$ & $\begin{array}{l}\text { duży } \\
\text { "big" }\end{array}$ & $\begin{array}{l}\text { dobry } \\
\text { "good" }\end{array}$ & $\begin{array}{c}\text { wysoki } \\
\text { "tall" }\end{array}$ & $\begin{array}{c}\text { piękny } \\
\text { "beautiful" }\end{array}$ \\
\hline $\begin{array}{l}\text { strasznie } \\
\text { "terribly" }\end{array}$ & $\begin{array}{l}\text { trudny } \\
\text { "difficult" }\end{array}$ & $\begin{array}{l}\text { zmęczony } \\
\text { "tired" }\end{array}$ & $\begin{array}{l}\text { nudny } \\
\text { "boring" }\end{array}$ & $\begin{array}{c}\text { maty } \\
\text { "small" }\end{array}$ & $\begin{array}{l}\text { smutny } \\
\text { "sad" }\end{array}$ \\
\hline $\begin{array}{c}\text { niezmiernie } \\
\text { "immeasurably" }\end{array}$ & $\begin{array}{c}\text { ważny } \\
\text { "important" }\end{array}$ & $\begin{array}{l}\text { trudny } \\
\text { "difficult" }\end{array}$ & $\begin{array}{c}\text { istotny } \\
\text { "essential" }\end{array}$ & $\begin{array}{l}\text { wdzięczny } \\
\text { "grateful" }\end{array}$ & $\begin{array}{c}\text { ciekawy } \\
\text { "interesting" }\end{array}$ \\
\hline $\begin{array}{c}\text { okropnie } \\
\text { "terribly"' }\end{array}$ & $\begin{array}{l}\text { nudny } \\
\text { "boring" }\end{array}$ & $\begin{array}{l}\text { zmęczony } \\
\text { "tired" }\end{array}$ & $\begin{array}{l}\text { smutny } \\
\text { "sad" }\end{array}$ & $\begin{array}{c}\text { gtodny } \\
\text { "hungry" }\end{array}$ & $\begin{array}{c}\text { drogi } \\
\text { "expensive" }\end{array}$ \\
\hline $\begin{array}{l}\text { niestychanie } \\
\text { "unheard-of" }\end{array}$ & $\begin{array}{c}\text { ważny } \\
\text { "important" }\end{array}$ & $\begin{array}{l}\text { trudny } \\
\text { "difficult" }\end{array}$ & $\begin{array}{c}\text { istotny } \\
\text { "essential" }\end{array}$ & $\begin{array}{l}\text { skomplikowany } \\
\text { "complicated" }\end{array}$ & $\begin{array}{l}\text { silny } \\
\text { "strong" }\end{array}$ \\
\hline $\begin{array}{l}\text { szalenie } \\
\text { "madly" }\end{array}$ & $\begin{array}{c}\text { ważny } \\
\text { "important" }\end{array}$ & $\begin{array}{c}\text { trudny } \\
\text { "difficult" }\end{array}$ & $\begin{array}{c}\text { istotny } \\
\text { "essential" }\end{array}$ & $\begin{array}{c}\text { ciekawy } \\
\text { "interesting" }\end{array}$ & $\begin{array}{c}\text { groźny } \\
\text { "threatening" }\end{array}$ \\
\hline $\begin{array}{l}\text { niesamowicie } \\
\text { "uncommonly" }\end{array}$ & $\begin{array}{l}\text { duży } \\
\text { "big" }\end{array}$ & $\begin{array}{c}\text { ważny } \\
\text { "important" }\end{array}$ & $\begin{array}{l}\text { trudny } \\
\text { "difficult" }\end{array}$ & $\begin{array}{c}\text { silny } \\
\text { "strong" }\end{array}$ & $\begin{array}{l}\text { szybki } \\
\text { "fast" }\end{array}$ \\
\hline $\begin{array}{c}\text { cholernie } \\
\text { "damnedly" }\end{array}$ & $\begin{array}{l}\text { trudny } \\
\text { "difficult" }\end{array}$ & $\begin{array}{c}\text { zazdrosny } \\
\text { "jealous" }\end{array}$ & $\begin{array}{c}\text { drogi } \\
\text { "expensive" }\end{array}$ & $\begin{array}{l}\text { szczesśliwy } \\
\text { "happy" }\end{array}$ & $\begin{array}{l}\text { dobry } \\
\text { "good" }\end{array}$ \\
\hline $\begin{array}{l}\text { potwornie } \\
\text { "terribly" }\end{array}$ & $\begin{array}{c}\text { zmęczony } \\
\text { "tired" }\end{array}$ & $\begin{array}{c}\text { drogi } \\
\text { "expensive" }\end{array}$ & $\begin{array}{l}\text { nudny } \\
\text { "boring" }\end{array}$ & $\begin{array}{l}\text { trudny } \\
\text { "difficult" }\end{array}$ & $\begin{array}{c}\text { ciężki } \\
\text { "difficult" }\end{array}$ \\
\hline $\begin{array}{l}\text { straszliwie } \\
\text { "horrifically" }\end{array}$ & $\begin{array}{l}\text { okaleczony } \\
\text { "maimed" }\end{array}$ & $\begin{array}{c}\text { zmęczony } \\
\text { "tired" }\end{array}$ & $\begin{array}{l}\text { zniszczony } \\
\text { "ruined" }\end{array}$ & $\begin{array}{l}\text { trudny } \\
\text { "difficult" }\end{array}$ & $\begin{array}{l}\text { zaniedbany } \\
\text { "neglected" }\end{array}$ \\
\hline $\begin{array}{l}\text { wściekle } \\
\text { "madly" }\end{array}$ & $\begin{array}{l}\text { różowy } \\
\text { "pink" }\end{array}$ & $\begin{array}{c}\text { gtodny } \\
\text { "hungry" }\end{array}$ & $\begin{array}{l}\text { kolorowy } \\
\text { "colorful" }\end{array}$ & $\begin{array}{l}\text { czerwony } \\
\text { "red" }\end{array}$ & \\
\hline $\begin{array}{c}\text { piekielnie } \\
\text { "infernally" }\end{array}$ & $\begin{array}{l}\text { trudny } \\
\text { "difficult" }\end{array}$ & $\begin{array}{c}\text { drogi } \\
\text { "expensive" }\end{array}$ & $\begin{array}{c}\text { mocny } \\
\text { "strong" }\end{array}$ & $\begin{array}{l}\text { inteligenty } \\
\text { "intelligent" }\end{array}$ & $\begin{array}{c}\text { silny } \\
\text { "strong" }\end{array}$ \\
\hline $\begin{array}{l}\text { niewiarygodnie } \\
\text { "unbelievably" }\end{array}$ & $\begin{array}{c}\text { wysoki } \\
\text { "high/tall" }\end{array}$ & $\begin{array}{c}\text { trudny } \\
\text { "difficult" }\end{array}$ & $\begin{array}{c}\text { wielki } \\
\text { "great"/“large" }\end{array}$ & $\begin{array}{l}\text { szybki } \\
\text { "fast" }\end{array}$ & $\begin{array}{c}\text { niski } \\
\text { "short" }\end{array}$ \\
\hline $\begin{array}{c}\text { bosko } \\
\text { "divinely" }\end{array}$ & $\begin{array}{l}\text { święty } \\
\text { "holy" }\end{array}$ & & & & \\
\hline $\begin{array}{l}\text { nadzwyczajnie } \\
\text { "unusually" }\end{array}$ & $\begin{array}{l}\text { wysoki } \\
\text { "tall" }\end{array}$ & $\begin{array}{c}\text { wielki } \\
\text { "great/large" }\end{array}$ & $\begin{array}{l}\text { duży } \\
\text { "big" }\end{array}$ & $\begin{array}{l}\text { trudny } \\
\text { "difficult" }\end{array}$ & $\begin{array}{c}\text { piękny } \\
\text { "beautiful" }\end{array}$ \\
\hline $\begin{array}{c}\text { bajecznie } \\
\text { "fabulously" }\end{array}$ & $\begin{array}{l}\text { kolorowy } \\
\text { "colorful" }\end{array}$ & $\begin{array}{l}\text { bogaty } \\
\text { "rich" }\end{array}$ & $\begin{array}{c}\text { prosty } \\
\text { "simple" }\end{array}$ & $\begin{array}{c}\text { piękny } \\
\text { "beautiful" }\end{array}$ & $\begin{array}{c}\text { tani } \\
\text { "cheap }\end{array}$ \\
\hline $\begin{array}{c}\text { nieludzko } \\
\text { "inhumanly" }\end{array}$ & $\begin{array}{c}\text { zmęczony } \\
\text { "tired" }\end{array}$ & $\begin{array}{l}\text { traktowany } \\
\text { "treated" }\end{array}$ & $\begin{array}{l}\text { cierpiacy } \\
\text { "suffering" }\end{array}$ & $\begin{array}{l}\text { zimny } \\
\text { "cold" }\end{array}$ & $\begin{array}{l}\text { doskonaty } \\
\text { "perfect" }\end{array}$ \\
\hline $\begin{array}{l}\text { skandalicznie } \\
\text { "scandalously" }\end{array}$ & $\begin{array}{c}\text { niski } \\
\text { "short" }\end{array}$ & $\begin{array}{c}\text { maty } \\
\text { "small" }\end{array}$ & $\begin{array}{l}\text { wysoki } \\
\text { "high" }\end{array}$ & $\begin{array}{c}z \text { zly } \\
\text { "bad" }\end{array}$ & \\
\hline $\begin{array}{l}\text { szaleńczo } \\
\text { "madly" }\end{array}$ & $\begin{array}{l}\text { zakochany } \\
\text { "in love" }\end{array}$ & $\begin{array}{l}\text { odważny } \\
\text { "brave" }\end{array}$ & $\begin{array}{c}\text { ambitny } \\
\text { "ambitious" }\end{array}$ & & \\
\hline
\end{tabular}


Pobrane z czasopisma Annales N - Educatio Nova http://educatio.annales.umcs.pl Data: 26/04/2023 12:05:37

Escape from Etymology? A Corpus Study of Polish Adjectival Intensifiers 469

\begin{tabular}{|c|c|c|l|l|l|}
\hline $\begin{array}{c}\text { diabelnie } \\
\text { "devilishly" }\end{array}$ & $\begin{array}{c}\text { trudny } \\
\text { "difficult" }\end{array}$ & $\begin{array}{c}\text { ciężki } \\
\text { "difficult" }\end{array}$ & & & \\
\hline $\begin{array}{c}\text { horrendalnie } \\
\text { "exorbitantly" }\end{array}$ & $\begin{array}{c}\text { wysoki } \\
\text { "high" }\end{array}$ & $\begin{array}{c}\text { drogi } \\
\text { "expensive" }\end{array}$ & & & \\
\hline $\begin{array}{c}\text { obtędnie } \\
\text { "madly" }\end{array}$ & $\begin{array}{c}\text { dziki } \\
\text { "wild" }\end{array}$ & $\begin{array}{c}\text { skomplikowany } \\
\text { "complicated" }\end{array}$ & $\begin{array}{c}\text { wysoki } \\
\text { "tall" }\end{array}$ & & \\
\hline $\begin{array}{c}\text { nieziemsko } \\
\text { "divinely" }\end{array}$ & $\begin{array}{c}\text { piękny } \\
\text { "beautiful" }\end{array}$ & $\begin{array}{c}\text { przystojny } \\
\text { "handsome" }\end{array}$ & & & \\
\hline $\begin{array}{c}\text { anielsko } \\
\text { "angelically" }\end{array}$ & $\begin{array}{c}\text { cierpliwy } \\
\text { "patient" }\end{array}$ & $\begin{array}{c}\text { piękny } \\
\text { "beautiful" }\end{array}$ & & & \\
\hline $\begin{array}{c}\text { bezdennie } \\
\text { "abysmally" }\end{array}$ & $\begin{array}{c}\text { gtupi } \\
\text { "stupid" }\end{array}$ & & & & \\
\hline $\begin{array}{c}\text { niebiańsko } \\
\text { "heavenly" }\end{array}$ & $\begin{array}{c}\text { piękny } \\
\text { "beautiful" }\end{array}$ & & & & \\
\hline
\end{tabular}

Source: Author's own study.

The next most frequent in the top six are adjectives ważny ("important") and istotny ("essential"/“important"). Again, this is not surprising given human nature: if something is important to us we are likely to say that it is very important. The collocations of bardzo/"very" and $w a \dot{z} n^{* / / i m p o r t a n t " ~ a r e ~ a l s o ~ h i g h ~ i n ~}$ NKJP and BNC: bardzo ważn" occurs 8.985 times in a 250 million word corpus and "very important" occurs 2,141 times per 100 million words.

Among other commonly intensified adjectives we find representatives of all three groups proposed by Grzegorczykowa: measurable qualities (wysoki ["tall"], niski ["short"], maty ["small"], duży ["big"], wielki ["large"]), judgments (piękny ["beautiful"], inteligentny ["intelligent"], dobry ["good"]) and psychological qualities (szczęśliwy ["happy"], smutny ["sad"], ciekawy ["interesting"], nudny ["boring"]). The adjectives zmęczony ["tired"] and gtodny ["hungry"], referring to physiological states can perhaps be characterized as judgments, or, in Janus' typology, physical states.

Another way to verify Grzegorczykowa's and Janus' claims is to look at which adjectives tend to occur with intensifiers. I examined 336 adjectives which were found five or more times with one or more of the 31 intensifiers considered. Many adjectives collocated only with a single intensifier (e.g. with wyjatkowo ["exceptionally"], strasznie ["terribly"], szalenie ["madly"], or straszliwie ["horribly"/"horrifically"]). Others collocated with only two (wyjatkowo and strasznie, wyjatkowo and niestychanie, wyjatkowo and szalenie), etc. Out of 336 adjectives, 29 occurred with five or more intensifiers. These are given in Table 9. Columns 3-13 in Table 9 list the number of concordances of each adjective/intensifier pair. Column 14 lists the total occurrences of an adjective with all ten intensifiers and the last column shows how many of the ten intensifiers the adjective collocated with.

Table 9 shows that trudny ("difficult") and ważny ("important") are the adjectives which are most often found with intensifiers. The numbers are quite striking, 
Pobrane z czasopisma Annales N - Educatio Nova http://educatio.annales.umcs.pl

Data: 26/04/2023 12:05:37

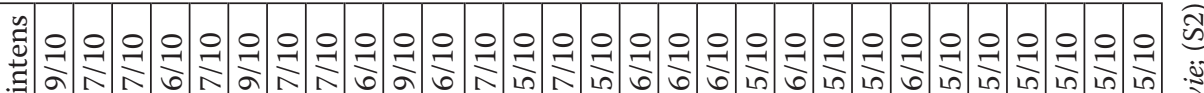

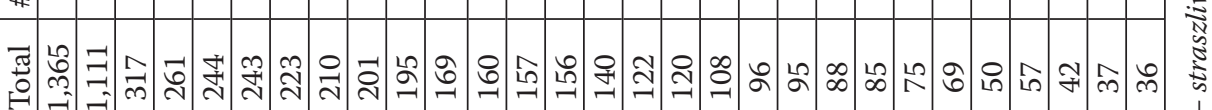

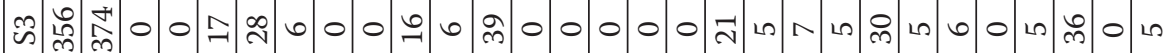

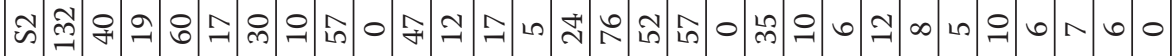

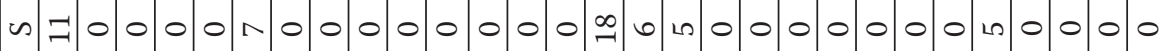

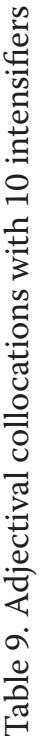

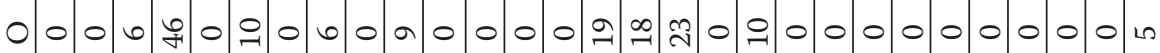

a I

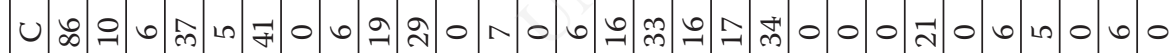

若

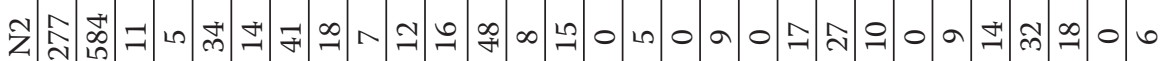

$Z$ Z

(2)

章

$\widehat{0}$

(2)

$\geqslant \infty$

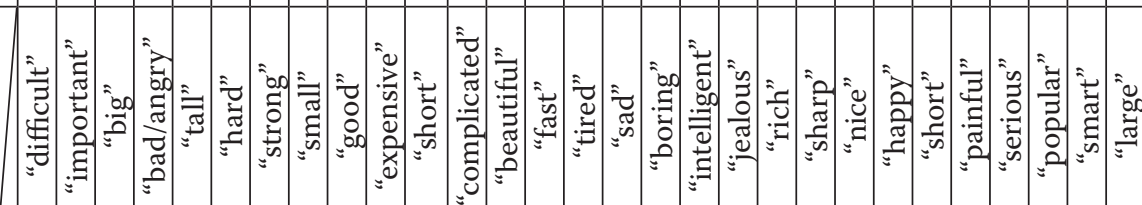

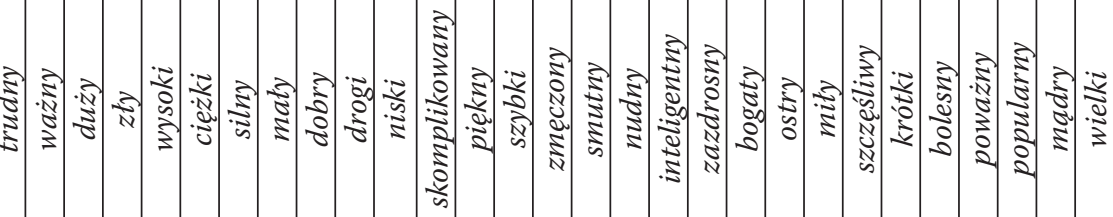

3 
with both trudny and wazny occurring with an intensifier over 1,100 times, while the next most often modified adjective $d u \dot{z} y$ ("big") is found with an intensifier only 317 times (roughly $1 / 3$ of the frequency of trudny and wazny), and the numbers diminish from there. It is also instructive to see that only three adjectives: trudny ("difficult"), ciężki ("difficult"/"heavy") and drogi ("expensive") occurred with nine out of ten intensifiers. The remaining 26 adjectives were much more picky.

Adjectives in Tables 8 and 9 largely overlap and the data in Table 9 also confirm Grzegorczykowa's and Janus' predictions. The top ten adjectives most frequently modified by intensifiers refer to difficulty, importance, quality (good/ bad), size, strength and price. However, based on this study, Grzegorczykowa's and Janus' order of adjectives most often modified by intensifiers should be adjusted: those expressing judgment (trudny ["difficult"], ważny ["important"]) are modified far more frequently than those expressing measurable quantities or psychological states.

\section{CONCLUSIONS}

This paper looked at the phenomenon of adjectival intensification from two directions. I examined 31 intensifiers and their frequencies (concordances) and collocations (which adjectives they occur with most frequently, at least 5 times in the corpus) to determine the degree of their semantic specificity and combinatorial freedom. It turns out that those which correspond to English "terribly"/"awfully" tend to collocate with negative adjectives. Negated intensifiers, imply crossing a limit or a line, but are found mostly with adjectives with positive meanings. Three of the four mad-based adverbs are very selective, as are intensifiers in the earth, heaven and hell group. Finally, the highly specialized group is very selective indeed and does not allow collocations beyond the chosen few. We have also seen that register plays a role, while strasznie ("terribly") is more mainstream than cholernie ("damnedly"), neither would be found with, e.g., radosny ("joyful", "joyous") which is of a higher register.

It turns out that the vast majority of intensifiers we considered do retain vestigial meanings of their roots and that this affects their selectional properties. Intensifiers express the fact that some gradable feature is present in the speakers' midst to an unexpected degree and their need to comment on it. The choice of intensifier is rarely random, it is often driven by the type of feeling this unexpected situation evokes. It expresses the speakers' judgments, attitudes and emotions about this unexpected turn of events. Some Polish intensifiers are very specialized, others are quite generic, and most are in between (wide-ranging but still affected by core meaning or register). 
Looking at this phenomenon from the adjectives' side, this study has brought a new result to the previous work (Grzegorczykowa [1975] and Janus [1981]). Based on corpus data, it turns out that the most often modified adjectives refer not to measurable qualities but to judgments, and especially difficulty and importance. Further avenues of study include a closer look at history. Bałabaniak and Mitrenga (2015) offer an excellent diachronic study of intensifiers themselves and their combinability, but it would be interesting to see which adjectives tended to be intensified over time.

\section{REFERENCES}

\section{Literature}

Bałabaniak, D., Mitrenga, B. (2015). Polskie intensyfikatory w ujęciu historycznym. Katowice: Wydawnictwo Uniwersytetu Śląskiego.

Bańkowski, A. (2000). Etymologiczny słownik języka polskiego. Warszawa: Wydawnictwo Naukowe PWN.

Bolinger, D. (1972). Degree Words. Berlin: De Gruyter.

Boryś, W. (2005). Stowniketymologiczny języka polskiego. Kraków: Wydawnictwo Literackie. Grzegorczykowa, R. (1975). Funkcje semantycznie i składniowe polskich przystówków.

Wrocław: Ossolineum.

Huddleston, R., Pullum, G. (2002). Adjectives and Adverbs. In: The Cambridge Grammar of the English Language (pp. 525-596). Cambridge: Cambridge University Press.

Janus, E. (1981). Wyktadniki intensywności cechy (na materiale polskim i rosyjskim). Wrocław: Zakład Narodowy im. Ossolińskich.

Partington, A. (1993). Corpus Evidence of Language Change - the Case of the Intensifier. In: M. Baker, G. Francis, E. Tognini-Bonelli (eds.) Text and Technology: In Honour of John Sinclair (pp. 177-192). Amsterdam: John Benjamins.

Stange, U. (2017). "You're So Not Going to Believe This": The Use of GenX so in Constructions with Future going to in American English. American Speech, vol. 92(4), 487-524, DOI: https://doi.org/10.1215/00031283-4395168.

Vosshagen, C. (1999). Opposition as a Metonymic Principle. In: K.-U. Panther, G. Radden (eds.), Metonymy in Language and Thought (pp. 289-308). Amsterdam-Philadelphia: John Benjamins.

Wierzbicka, A. (1969). Dociekania semantyczne. Wrocław: Zakład Narodowy im. Ossolińskich.

Wierzbicka, A. (1971). Kocha, lubi, szanuje. Medytacje semantyczne. Warszawa: Wiedza Powszechna.

\section{Websites}

BNC. www.english-corpora.org/bnc [access: 10.09.2020].

Polish National Corpus. www.nkjp.pl [access: 10.09.2020]. 